\title{
Aspek Hukum Dalam studi kelayakan bisnis
}

Makalah Ini Disusun Untuk Memenuhi Tugas Pada Mata Kuliah Studi Kelayakan Bisnis

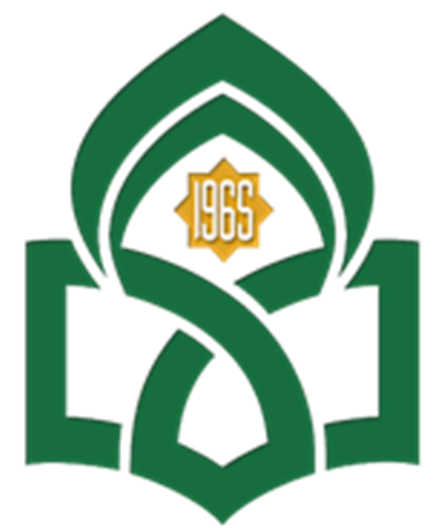

UNIVERSITAS ISLAM NEGERI

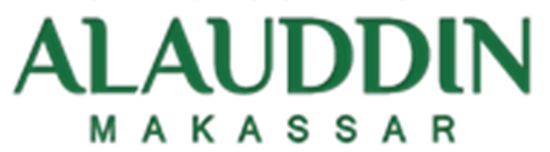

DAHLIA

90500120006

PRODI PERBANKAN SYARIAH

FAKULTAS EKONOMI DAN BISNIS ISLAM

UNIVERSITAS ISLAM NEGERI ALAUDDIN MAKASSA

2021 


\begin{abstract}
ABSTRAK
Aspek hukum merupakan aspek terpenting dalam suatu perjanjian, karena dengan memperhatikan aspek hukum, maka para pihak akan dapat mengantisipasi persoalanpersoalan yang akan timbul dalam perjanjian. Hal itu dikarenakan para pihak yang bersangkutan dalam proses terjadinya sebuah buku, terutama pihak penerbit dan pengarang akan mengetahui hak-hak apa saja yang dimilikinya dan kewajiban-kewajiban apa saja yang harus dijalankannya. Hal yang lebih penting lagi adalah para pihak dapat mengetahui bagaimana jalan keluar apabila ternyata masih terjadi suatu perselisihan atau persengketaan, sehingga dengan demikian akan diperoleh suatu penyelesaian yang dapat memuaskan kedua pihak dan mengurangi kerugian yang timbul akibat terbuangnya waktu, tenaga dan biaya.
\end{abstract}




\section{KATA PENGANTAR}

Puji syukur kehadirat Allah SWT yang telah memberikan rahmat dan hidayah-Nya sehingga kami dapat menyelesaikan tugas makalah yang berjudul "Analisis Aspek Hukum" ini tepat pada waktunya.

Adapun tujuan penulisan dari makalah ini adalah untuk memenuhi tugas pada mata kuliah Studi kelayakan bisnis. Selain itu, makalah ini juga bertujuan untuk menambah wawasan tentang Perbankan Syariah bagi para pembaca dan juga bagi penulis.

Kami mengucapkan terima kasih kepada bapak ibu ST.HAFSAH UMAR ,M.AK. selaku dosen pada mata kuliah Studi kelayakan bisnis yang telah memberikan tugas ini sehingga dapat menambah pengetahuan dan wawasan sesuai dengan bidang studi yang kami tekuni.

Kami menyadari, makalah yang tulis ini masih jauh dari kata sempurna. Oleh karena itu, kritik dan saran yang membangun akan kami nantikan demi kesempurnaan makalah ini.

Makassar, 8 November 2021

Penulis 
DAFTAR ISI

ABSTRAK

KATA PENGANTAR

BAB I PENDAHULUAN
A. Latar Belakang
B. Rumusan Malasah
C. Tujuan

BAB II PEMBAHASAN

Aspek hukum

a.Pengertiam Aspek Hukum

b.Tujuan Aspek Hukum

c.Bentuk-Bentuk Badan Hukum

d.Cara Pelaksanaan Bisnis

e. Peraturan dan perundangan

\section{BAB III PENUTUP}

Kesimpulan

DAFTAR REFERENSI 


\section{BAB I}

\section{PENDAHULUAN}

\section{A. Latar Belakang}

sering kali mengalami kegagalan karena terbentur masalah hokum atau tidak memperoleh izin dari pemerintah setempat.Oleh karena itu, sebelum ide bisnis dilaksanakan, analisis secara mendalam terhadap aspek hokum harus dilakukan agar dikemudian hari bisnis hokum yang dilaksanakan tidak gagal karena terbentur permasalahan hokum dan perizinan.Aspek hokum merupakan aspek yang kali pertama harus dikaji. Hal ini karena jika berdasarkan analisis pada aspek hokum sebuah ide bisnis sudah tidak layak maka proses tersebut tidak perlu diteruskan dengan analisis pada aspek-aspek yang lain.

Aspek hukum mengkaji ketentuan hukum yang harus dipenuhi sebelum menjalankan usaha.Ketentuan hukum untuk jenis usaha berbeda-beda, tergatung pada kompleksitas bisnis tersebut. Adanya otonomi daerah menyebabkan ketentuan hukum dan perizinan antara daerah yang satu dengan daerah yang lain berbeda-beda. Oleh karena itu, pemahaman mengenai ketentuan hokum dan perizinan investasi untuk setiap daerah merupakan hal yang sangat penting untuk melakukan analisis kelayakan aspek hukum..

Masalah yang timbul kadang kala sangat vital, sehingga usaha yang semula dinyatakan layak dari semua aspek, ternyata menjadi sebaliknya. Hal tersebut dapat terjadi karena kurangnya ketelitian dalam penilaian dari segi keabsahan atau kelegalitasan di bidang hukum dan lain sebagainya sebelum usaha tersebut dijalankan. 


\section{B. Rumusan Masalah}

Berdasarkan latar belakang yang telah dituliskan diatas, makalah ini dijabarkan dari rumusan masalah sebagai berikut :

1. Apakah yang dimaksud dengan Aspek Hukum?

2. Apa tujuan dan fungsi dari Aspek Hukum?

3. Apa perbedaan dari akuntansi syariah dan akuntansi konvensional ?

4. Bagaimanakah pengoprasionalan akuntansi syariah pada lembaga keuangan bank dan non bank?

\section{Tujuan}

Analisis aspek hukum dilakukan dengan tujuan menjawab pertanyaan "Apakah bisnis

Yang akan dijalankan dapat memebuhi ketentuan hukum dan perizinan Di suatu wilayah?"

Sacara spesifik analisis aspek hukum pada studi kelayakan bisnis bertujuan untuk :

1.Menganalisis legalitas atas usaha yang akan dijalankan

2.Menganalisis ketepatan bentuk badan hukum dengan ide bisnis yang akandilaksanakan

3.Menganalisis kemampuan bisnis yang akan diusulkan dalam memenuhi persyaratanperizinan

4.Menganalisis jaminan-jaminan yang bisa disediakan jika bisnis akan dibiayai denganpinjaman 


\section{PEMBAHASAN}

\section{1..ASPEK HUKUM}

\section{A. Pengertian Aspek Hukum}

Ketika membangun sebuah usaha bisnis seringkali mengalami kegagalan karena terbentur masalah hukum atau tidak memperoleh izin dari pemerintah daerah setempat. Oleh karena itu, sebelum ide bisnis dilaksanakan, analisis secara mendalam terhadap aspek hukum harus dilakukan agar di kemudian hari bisnis yang akan dilaksanakan tidak gagal karena terbentur permasalahan hukum dan perizinan. Aspek hukum merupakan aspek yang kali pertama harus dikaji. Hal ini karena jika berdasarkan analisis pada aspek hukum sebuah ide bisnis sudah tidak layak maka proses tersebut tidak perlu diteruskan dengan analisis pada aspek-aspek yang lain.

Aspek hukum adalah aspek yang mengkaji ketentuan hukum yang harus dipenuhi sebelum menjalankan usaha. Ketentuan hukum untuk setiap jenis usaha berbeda-beda, tergantung pada kompleksitas bisnis tersebut. Adanya otonomi daerah menyebabkan ketentuan hukum dan perizinan antara daerah yang satu dengan daerah yang lain berbeda-beda. Oleh karena itu, pemahaman mengenai ketentuan hukum dan perizinan investasi untuk setiap daerah merupakan hal yang sangat penting untuk melakukan analisis kelayakan aspek hukum. Pemerintah menetapkan ketentuan hukum dan perizinan investasi dengan tujuan menjaga ketertiban masyarakat secara luas. Masyarakat di sekitar lokasi bisnis diharapkan akan mendapatkan manfaat yang besar dibandingkan dengan dampak negatif dari adanya suatu invndirian 
usaha(pendirian badan usaha), ijin produk, ijin lokasi, dan ijin investasi. Manfaat dari ijin yangdiajukan ini diantaranya adalah sebagai berikut :

1. Ijin Pendirian Usaha :- Merupakan ajang promosi sehingga memudahkan pemasaran produknya- Untuk memperoleh kepastian usahasehingga memudahkan kerjasama dan/atauperluasan usaha dengan adanya penanaman modal dari pihak lain yang berminat.Mendapatkan pembinaan dan dukungan pemerintah mengenai permodalandengan kredit prioritas, pameran produk, serta manajemen usaha.- Terlindungi dari praktek usaha yang tidak jujur.

2. Ijin produk :- Membangun kepercayaan konsumen terhadap keamanan produk. Contohnya:Standar kualitas (SNI), makanan aman konsumsi (BPOM, Halal)

3. Ijin lokasi :- Keamanan dan ketenangan dalam menjalankan suatu usaha di suatu lokasi.Adanya dukungan dari masyarakat sekitar.

4. Ijin Investasi :- Agar masyarakat mendapatkan manfaat yang lebih besar dibandingkan dengandampak negatif dari adanya suatu investasi bisnis.Dari penjelasan beberapa manfaat yang didapatkan dengan memenuhi aspek hokumdalam studi kelayakan bisnis, maka dapat di simpulkan bahwa aspek hukum sangatpenting dan berperan dalam kelangsungan bisnis suatu perusahaan, disetiap tahap danproses perusahaan. Aspek hukum dapat mempengaruhi setiap aspek-aspek dalam SKB,sehingga aspek hukum penting untuk diperhatikan sebelum mendirikan suatu usaha.

Setiap pengusaha menghendaki adanyaketenangan dan keberlanjutan usaha.Hal teranusaha.Hal tersebut dapat dicapai jika lingkunganusaha menerima dan mendukung keberadaanusaha.Keberadaan usaha yang dapat diterima olehlingkungan biasanya mampu 
memberikankemanfaatan bagi semua komponen masayrakatsekitarnya.Keberlanjutan usaha selain ditentukanoleh factor-faktor fundamental bisnis berupa pasar,produksi, sumber daya manusia dan keuangan jugaharus ditunjang adanya legalitas usaha. Sebaikapapun prospek bisnis yang akan dijalankan,secanggih apapun teknologi dan operasi,seprofesional apapun personalia dan sesolid danselukuid apapun sumber keuangannya, namun jikalegalitas usaha tidak ada atau tidak dapat diperolehdari otoritas pemerintah melalui instansi/departementerkait, usaha tersebut tidak akan dapat beroperasidalam waktu yang lama dan berkelanjutan, sehingga

Dengan legalitas usaha (memenuhi syarat aspekhukum).Analisis aspek hukum dimaksudkan untukmeyakini apakah secara hokum (yuridis) rencanabisnis dapat dinyatakan layak atau tidak. Jika suaturencana bisnis yang tidak layak tetap direalisasikan, bisnis akan mengalami resiko yang besar terutamaakan dihentikan pleh pihak yang berwajib atau akandi protes oleh masyarakat. Analisis aspek hokummengkaji tentang legalitas rencana bisnis yang akandibangun serta dioperasikan di wilayah tertentu harusmemenuhi aturan hokum dan tata peraturan yangberlaku di wilayah tersebut. Keterlanjuran investasidi suatu daerah/wilayah yang ternyata melarangusaha yang akan dilakukan akan menimbulkankerugian besar. Di pandang dari sudut sumbernya,bentuk legalitas dapat dibedakan menjadi 2 sumber,yaitu:

1.Kelompok masyarakat, yaitu kelompokmasyarakat yang hidup dan tinggal di daerah /wilayah tempat proyek/bisnis yang akandidirikan. Masyarakat ini dapat menjadi Bagian dari system dan struktur pemerintahanataupun kelompok adat/suku. Misalnya,dalam struktur pemerintahan terdapat rukuntetangga(RT), rukun warga $(\mathrm{RW})$,desa/kelurahan, kecamatan, kabupaten/kota.Selain itu terdapat kelompok adat/suku,misalnya suku/adat Minang, Dayak,Bugis,dan sebagainya yang menguasai tanah ulayat. 
2.Pemerintah, yang merupakan bagian daristruktur dan system pemerintah Indonesiatermasuk lembaga pemerintah dari desasampai Negara sertainstansi/lembaga/departemen yangmembidangi sector-sektor tertentu.Untuk mendapatkan legalitas usaha,kedua sumber tersebut di atas harusdiperhatikan.Untuk mendapatkanperizinan/legalitas pemerintah, perusahaan harusterlebih dahulu mendapatkan persetujuankelompok masyarakat. Misalnya, perusahaanyang ingin mendapatkan izin mendirikan uasahaperdagangan (SIUP) dari pemda setempat Terlebih dahulu harus meminta surat keterangandomisili usaha yang dikeluarkan oleh kepaladesa/lurah dengan sepengetahuan RT/RWsetempat dimana lokasi usaha tersebut akandidirikan.Usaha dapat dikatakan legal jika telahmendapatkan izin usaha dari pemerintah daerahsetempat melaluiinstansi/lembaga/departemen/dinasterkait.Namun, analis dan investor perlumemperhatikan sumber legal dari kelompokmasyarakat.Sering terjadi ketika pemerintah telahmengijinkan suatu usaha, tetapi masyarakat yangtinggal di sekitar lokasi usaha menolak, sehinggausaha tidak dapat berjalan secara wajar.Hal iniakan sangat merugikan bagi perjalanan bisnisselanjutnya, bahkan perusahaan dapat bangkrutdan ditutup.Untuk mengetahui apakah suatu rencanabisnis diyakini layak dari segi hokum dapatdipelajari dari berbagai sisi, diantaranya adalahbentuk jenis usaha, identitas pelaksana bisnis,

Bisnis apa yang akan dikerjakan, waktupelaksanaan dan tempat dimana rencana bisnistersebut akan dilaksanakan. Kajian hokumterdapat rencana bisnis tersebut hendaknyamenggunakan peraturan-peraturan yang berlaku,sehingga setelah dikaji secara seksama, akantampak jelas layak atau tidaknya rencana bisnistersebut dilihat dari aspek 
hukum.Dalam aspek hukum dan legalitas ini, adabeberapa faktor yang dijadikan dasar dalampenilaian kelayakan. Faktor-faktor tersebutadalah :

a.Badan hukum apa yang sesuai untuk dijadikanbentuk formal badan usaha yag akan didirikan

.b.Komoditas usaha termasuk jenis barangdagangan (komoditas) yang diperbolehkan ataudilarang undang-undangc.

\title{
B. Tujuan Aspek Hukum
}

Aspek hukum dilakukan dengan tujuan menjawab pertanyaan "Apakah bisnis yang akan dijalankan dapat memenuhi ketentuan hukum dan perizinan di suatu wilayah? Berdasarkan aspek hukum, suatu ide bisnis dinyatakan layak jika ide bisnis tersebut sesuai dengan ketentuan hukum dan mampu memenuhi segala persyaratan perizinan di wilayah tersebut. Secara spesifik analis aspek hukum pada studi kelayakan bisnis bertujuan untuk:

Menganalis legalitas usaha yang akan dijalankan,Menganalisis ketepatan bentuk badan hukum dengan ide bisnis yang akan dilaksanakan,Menganalisis kemampuan bisnis yang akan diusulkan dalam memenuhi persyaratan perizinan,Menganalisis jaminan-jaminan yang bisa disediakan jika bisnis akan dibiayai dengan pinjaman

\author{
C. Bentuk-Bentuk Badan Hukum
}

Beberapa bentuk perusahaan dari sisi aspek hukum adalah: 
Agar rencana bisnis dapat berjalan dengan lancarserta sesuai dengan koridor-koridor hokum yangberlaku, maka diperlukan data tentang siapapelaksana bisnis tersebut. Untuk menganalisis siapapelaksana bisnis tersebut, maka yang pertama harusdiketahui adalah badan usahanya dan yagn keduaadalah orang-orang atau individu-individu yangterlibat sebagai pengambilan keputusan

\section{Badan Usaha Perseorangan / Individu}

Perusahaan jenis ini biasanya diawasi dandikelola seseorang . di satu pihak ia memperolehsemua keuntungan perusahaan, selainmenanggung semua risiko yang timbul dalamkegiatan. Biasanya, bentuk izin usahanya adalahusaha dagang (UD) dan perusahaan dagang (PD)dengan izin operasional berupa SIUP kecil yangdapat diperoleh di Dinas perdagangan atauDisperindag (Dinas perindutrian danperdagangan). Perusahaan perseorangan inibelum membutuhkan akta pendirian walaupun.Untuk mendapat perlindungan hukumperusahaan ini harus di daftarkan pada instansiterkait sehingga memperoleh status terdaftar.Status ini penting karena akan mendapat fasilitasbantuan dari pemerintah, dapat fasilitas kredit Dari bank, dilindungi pemeirntahan danberpeluang mengembangkan usaha, sehinggadiperlukan surat ijin.

\section{2..firma(fa)}

Firma adalah suatu bentuk perkumpulan usaha yang didirikan oleh beberapa orang dengan menggunakan nama bersama. Didalam firma semua anggota mempunyai tanggung jawab sepenuhnya baik sendiri-sendiri maupun bersama — sama terhadap utang-utang perusahan pada 
pihak lain. Bila terjadi kerugian maka kerugian ditanggung bersama, bila perlu dengan seluruh kekayaan pribadi. Jika salah satu anggota keluar dari firma, firma otomatis bubar. Badan usaha ini dimiliki oleh lebih darisatu orang dengan perjanjian tertentu. Biasanyapemilik firma adalah orang yang sangat dekatmisalnya keluarga atau famili. Oleh karenapemilik perusahaan lebih dari satu orang makaharus didaftarkan pada akta notaris kemudiandidaftarkan pada panitera pengadilan setempatdan diumumkan dalam berita negara. Secarahukum perjanjian antar pemilik akan lebih kuat.Kepemimpinan perusahaan biasanya ditentukandengan cara kesepakatan bersama, karena merekabertanggung jawab penuh terhadap badan usahaini.Firma adalah rapa orang sepenuhnya baik sendiri-sendiri maupunbersama-sama terhadap utang-utang perusahaanpada pihak lain. Bila terjadi kerugian, kerugianitu akan ditanggung bersama, bila perlu denganseluruh kekayaan pribadi . jika salah satu anggotakeluar dari firma , firma otomatis bubar . bentukfirma ini sudah jarang dijumpai di Indonesia ,mungkin kurang diminati, karena pertimbanganfactor risiko yang dianggap terlalu besar bagisebagian investor

\section{Perseroan Komanditer (CV).}

$\mathrm{CV}$ merupakan suatu persekutuan yang didirikan oleh beberapa orang yang masing-masing menyerahkan sejumlah uang dalam jumlah yang tidak perlu sama. Sekutu dalam Perseroan Komanditer ini ada dua macam, ada yang disebut sekutu komplementer yaitu orang-oarng yang bersedia untuk mengatur perusahaan dan sekutu komanditer yang mempercayakan uangnya dan bertanggung jawab terbatas kepada kekayaan yang diikutsertakan dalam perusahaan. Perseroan komanditer (CV) merupakanpersekutuan yang didirikan ole beberapa orangdengan masingmasing menyerahkan sejumlahuang yang tidak perlu sama . sekutu dalamperseroan komanditer ini ada 2 macam, yaitu: 
Sekutu aktif (komplementer/persero), yaituorang-orang yang bersedia mengaturperusahaan. Tanggung jawab sekutu ini tidakhanya terbatas pada modal yang ditanamkantetapi juga atas hatra kekayaan pribadi,Sekutu pasif komanditer, yaitu orang-orangyang mempercayakan modal usahanya danbertanggung jawab sebatas modal yangdiikutsertakan dalam perusahaan.Keuntungan yang diperoleh perusahaan

\section{Perseroan Terbatas (PT).}

Badan jenis ini adalah suatu badan usaha yang mempunyai kekayaan,hak, dan kewajibab yang terpisah dari yang mendirikan dan yang dimiliki. Tanda keikutsertan seseorang memiliki perusahaan adalah dengan memiliki saham perusahaan, makin banyak saham yang dimiliki makin besar pula andil dan kedudukannya dalam perusahaan tersebut. Jika terjadi utang, maka harta milik pribadi tidak dapat dipertanggungkan atas utang perusahaan tersebut, tetapi terbatas pada sahamnya saja. Perseroan terbatas adalah perusahaanyang terdiri dari dua orang atau lebih denganmodal yang diperoleh dengan penjualan atassaham-saham. Semua pemilik perusahaan adalahpemilik perusahaan. Tanggung jawab persero(pemegang saham) hanya sebatas pada modalyang disertakan besarnya modal persero. Ditentukan dengan anggaran dasar. Perseroanterbatas merupakan badan hukum yangmempunyai kekayaan perusahaan sendiri,sehingga tagihan hutang-hutang perusahaan ditanggung oleh harta persero.Badan usaha jenis ini adalah badan usahayang mempunyai kekayaan, hak milik, dan tandakeikutsertaan seseorang memiliki perusahaanmelalui saham perusahaan. Makin banyak sahamyang dimiliki, makin besar pula andil dankedudukannya dalam perusahaan tersebut. Jikaterjadi utang, harta milik pribadi tidak dapatdipertanggungkan atas utang perusahaan tersebut, tetapi terbatas pada sahamnya saja.Untuk mendirikan perseroan terbatas iniharus dengan akta pendirian yang 
disyahkan olehakta notaris yang disetujui oleh menterikehakiman. Keuntungan-keuntungan dibagikandalam bentuk deviden yang dibagikanberdasarkan besarnya saham

\section{Perusahaan Negara (PN).}

Perusahaan negara adalah perusahaan yang bergerak dalam bidang usaha yang modalnya secara keseluruhan dimiliki oleh negara, kecuali ada hal-hal yang khusus berdasarkan ungdangundang. Tujuan dari pendirian perusahaan negara adalah untuk membangun ekonomi nasional menuju masyrakat yang adil dan makmur. Perusahaan Negara atau sering disebutBUMN (badan usaha milik Negara) adalahperusahaan yang bergerak dalam bidang usahayang modalnya ecara keseluruhan dimilikiNegara, kecuali jika ada hal-hal khususberdasarkan undang-undang. Tujuan pendirianperusahaan ini adalah membangun ekonominasional menuju masyarakat adil makmur.

\section{Koperasi.}

Koperasi merupakan bentuk badan usaha yang bergerak di bidang ekonomi yang bertujuan untuk meningkatkan kersejahteraan anggotanya yang bersifat murni, pribadi dan tidak dapat dialihkan. Jadi ia merupakan suatu wadah yang penting untuk kesejahteraan anggota berdasarkan persamaan. Koperasi merupakan bentuk badan usahayang bergerak di bidang ekonomi yang bertujuanmeningkatkan kesejahteraan anggotanya; sifatnyamurni pribadi dan tidak dapat dialihkan. Jadi,badan usaha ini merupakan wadah penting untukkesejahteraan anggota berdasarkan persamaan.Menurut bidang usaha, koperasi dikelompokkanmenjadi koperasi produksi, koperasi konsumsi,koperasi simpan pinjam, dan koperasi serbausaha.Menurut luas usahanya, koperasi terdiriatas primer koperasi (Primkop), pusat koperasi(Puskop), gabungan koperasi (Gakop), dan indukkoperasi (Inkop) sebagai satuan terkecil yangmelibatkan secara langsung anggotanya. Pusatkoperasi merupakan gabungan paling sedikit 5primer koperasi. 
Gabungan koperasi merupakangabungan paling sedikit tiga puskop. Dan, indukkoperasi merupakan

\section{Cara Pelaksanaan Bisnis}

Ketika misalnya perusahaan kekurangan modal untuk menyelesaikan proyek, meminjam uang dari perorangan atau lembaga keuangan adalah beberapa alternatif untuk mengatasi kesulitan itu. Lembaga keuangan sebagai peminjam telah menentukan syarat-syarat dalam rangka pengamanan secara hukum, baik yang bersifat pencegahan maupun penanggulangan. Syarat-syarat tersebut antara lain yaitu :

\section{a. Pencegahan}

Contoh pencegahan yang disyaratkanoleh lembaga keuangan yang bersangkutan terhadap calon debitur misalnya, setiap penggantian persero pada Perseroan Komanditer atau pemegang saham pada pada Perseroan Terbatas, sebelumnya harus mendapat persetujuan dari lembaga keuangan yang akan menjadi kreditur.

\section{b. Penanggulangan}

Terdapat dua cara penanggulangan, yaitu sebagai berikut:

1).jaminam 
Jaminan memiliki dua fungsi pokok, yaitu sebagai stimulan kesungguhan sponsor proyek dan dapat mengatasi kesulitan debitur dalam memenuhi kewajibannya.

Jenis jaminan bisa dibagi menjadi dua, yaitu jaminan atas benda dan janji tidak bersyarat atau jaminan perorangan. Jaminan atas benda bisa berupa proyek itu sendiri dan jaminan tambahan. Sedangkan janji tidak bersyarat diberikan oleh sponsor proyek atau bisa pula dilakukan oleh pihak ketiga, misalnya bisnis induk dari calon debitur. Jaminan atas benda, baik berupa proyek maupun jaminan tambahan biasanya berupa tanah, bangunan, mesin-mesin, dan peralatan, serta piutang.

2).klausula

Dalam hal kreditur menerima barang-barang jaminan kredit dan diasuransikan maka kreditur harus mensyaratkan dalam pengansurasiannya dengan pencantuman klausula bank. Artinya, setiap ganti rugi yang diberikan penanggung kepada tertanggung harus diterima kreditur.

\section{E. Peraturan dan perundangan}

Peraturan pemerintah berkaitan dengan aspek yuridis yang harus dipatuhi dalam pendirian suatu usaha,antara lain:

1) UU No. 40 Tahun 2007 tentang Perseroan Terbatas

2) PP No. 63 Tahun 2008 tentang Yayasan

3) UU No.25 Tahun 1995 tentang Koperasi 
4) UU No.13 Tahun 1995 tentang Izin Usaha Industri

5) Peraturan Menteri Perdagangan RI No. 13/M-DAG/PER/3/2006 tentang Ketentan dan Tata Cara Penerbitan Surat Izin Usaha Penjualan Langsung

6) UU No. 19 Tahun 2003 tentang Badan Usaha Milik Negara

7) UU No.5 Tahun 1962 tentang Perusahaan Daerah

8) PP No. 10 Tahun 2004 tentang Perusahaan Perseroan dibidang Pengelolaan Aset.

\section{BAB III \\ PENUTUP}

\section{A.Kesimpupan}

Untuk memulai suatu usaha pada umumnya dimulai dari Aspek Hukum, walaupun banyak pula yang melakukannya dari aspek lain. Di dalam melakukan suatu usaha maka perlu diperhatikan berbagai dokumen yang bisa sesuai dengan badan Hukum yang berlaku,dokumen yang perlu diteliti keabsahan, kesempurnaan dan keasliannya meliputi badanhukum, izin-izin 
yang dimiliki, sertifikat tanah atau dokumen lainnya yang mendukungkegiatan usaha tersebut. Kegagalan dalam penelitian aspek ini akan berakibat tidaksempurnanya hasil penelitian, dengan kata lain apabila ada dokumen yang tidak sah atautidak sempurna pasti akan menimbulkan masalah dikemudian hari.Tujuan dari aspek hukum ini adalah untuk meneliti keabsahan, kesempurnaan dankeaslian dari dokumen-dokumen yang diteliti.penelitian keabsahan dapat dilakukan sesuaidengan lembaga yag mengeluarkan dan yang mengesahkan dokumen yang bersangkutan, penelitian ini sangat penting mengingat sebelum usaha tersebut dijalankan,maka segala prosedur yang berkaitan dengan izin-izin atau berbagai persyaratan harus terlebih dahulu 


\section{DAFTAR REFERENSI}

Husain, Umar. 2003. Studi Kelayakan Bisnis (Edisi 2), Teknik Menganalisis Kelayakan Rencana Bisnis Secara Komprehensif. (Jakarta : Gramedia Pustaka Utama)

Kasmir, Jakfar. 2006. Studi Kelayakan Bisnis, (Jakarta: Kencana)

Jumingan. 2009. Studi Kelayakan Bisnis : Teori dan Pembuatan Proposal Kelayakan, (Jakarta: PT Bumi Angkasa)

Husein Umar :Studi kelayakan Bisnis. Edisi-1, Jakarta:PT. Gramedia Pustaka Utama, 2000Husein Umar : Manajemen Risiko Bisnis. Jakarta: PT.

Rahmawati, windah. 2011.Pentingnya Wajib Daftar Perusahaan dan Peranan Wajib daftarPerusahaan Bagi Perkembangan Perekonomian Bangsa (online) .http:/Windahrahmawati.wordpress.com/pentingnya-wajib-daftar-perusahaan-danperanan-wajib-daftar-perusahaan-bagiperkembangan-perekonomian-bangsa/. DiaksesPada 6 Desember 2014 